\title{
Implementasi Layanan Konseling dengan Methode Reinforcement Guna Meningkatkan Motivasi Belajar Pada Siswa Kelas XI IPA 3 SMAN 5 Kota Jambi Tahun Pelajaran 2014/2015
}

\author{
Selma Br Hutabarat \\ Guru SMA 5 Kota Jambi
}

\begin{abstract}
Abstrak. Tujuan penelitian ini adalah: (a) Untuk mengungkap pengaruh Pembelajaran Metode Reinforcemen terhadap motivasi belajar. (b) Ingin mengetahui seberapa jauh motivasi belajar setelah diterapkannya Pembelajaran Metode Reinforcement. Penelitian ini menggunakan penelitian tindakan (action research) sebanyak tiga putaran. Setiap putaran terdiri dari empat tahap yaitu: rancangan, kegiatan dan pengamatan, refleksi, dan refisi. Sasaran penelitian ini adalah siswa kelas XI IPA 3 di SMA N 5 Kota Jambi. Teknik analisa data yang digunakan dalam penelitian ini adalah deskriptif kuantitatif, yaitu suatu metode penelitian yang bersifat menggambarkan kenyataan atau fakta sesuai dengan data yang diperoleh dengan tujuan untuk mengetahui prestasi belajar yang dicapai siswa juga untuk memperoleh respon siswa terhadap kegiatan pembelajaran serta aktivitas siswa selama proses pembelajaran. Analisa ini dihitung dengan menggunakan statistic sederhana. Data yang diperoleh berupa hasil tes formatif, lembar observasi kegiatan belajar mengajar. Dari hasil analis didapatkan bahwa prestasi belajar siswa mengalami peningkatan dari siklus I sampai siklus III yaitu, siklus I (57\%), siklus II (71\%), siklus III (88\%). Simpulan dari penelitian ini adalah metode Reinforcement dapat berpengaruh positif terhadap motivasi belajar Siswa kelas XI, serta model pembelajaran ini dapat digunakan sebagai salah satu alternative Bimbingan Konseling.
\end{abstract}

Kata Kunci: Bimbingan Konseling

Abstract. The purpose of this study is: (a) To reveal the effect of Learning Learning Method on learning motivation. (b) Want to find out how far the motivation to learn after applying the Reinforcement Learning Method. This research uses action research as much as three rounds. Each round consists of four stages, namely: design, activity and observation, reflection, and revision. The targets of this study were students of Class XI Science 3 in SMA N 5 Kota Jambi.The data analysis technique used in this study is quantitative descriptive, which is a research method that is describing the facts or facts in accordance with the data obtained with the aim to find out the learning achievements of students as well as to obtain student responses to learning activities and student activities during the learning process. This analysis is calculated using simple statistics. The data obtained in the form of formative test results, observation sheets of teaching and learning activities. From the results of analysts it was found that student achievement increased from cycle I to cycle III namely, cycle I (57\%), cycle II (71\%), cycle III (88\%). The conclusion of this research is the Reinforcement method can positively influence the learning motivation of Grade XI students, and this learning model can be used as an alternative to Counseling Guidance.

Keywords: Counseling Guidance

\section{PENDAHULUAN}

Bimbingan adalah pemberian bantuan kepada seseorang atau kepada sekelompok orang dalam membuat pilihan-pilihan secara bijaksana dan dalam mengadakan penyesuaian diri terhadap tuntutan-tuntutan hidup. Bimbingan di sekolah merupakan kegiatan informasi kepada siswa untuk membantu mereka menyusun rencana dan keputusan yang tepat. Sedangkan konseling adalah hubungan timbal balik diantara dua orang individu, dimana konselor berusaha membantu klien untuk mencapai atau mewujudkan pemahaman tentang dirinya sendiri dalam kaitannya dalam masalah atau kesulitan yang dihadapinya pada saat ini dan pada waktu mendatang.

Program bimbingan konseling ini lebih optimal untuk menangani masalah yang dihadapi oleh siswa pada tahap perkembangan remaja. Salah satu tujuan bimbingan konseling adalah untuk belajar percaya pada diri sendiri dan orang lain, Belajar bersosialisasi secara optimal dan menciptakan tanggung jawab sendiri dan orang lain, sehingga beberapa permasalahan yang berhubungan dengan masalah sosial siswa semua dapat dibantu melalui bimbingan konseling termasuk dalam hal perilaku negatif siswa. Belajar adalah inti dari kegiatan sekolah, maka guru berkewajiban untuk membantu mengatasi kesulitan belajar yang dihadapi siswa dengan cara memberikan bimbingan yang sesuai kesulitan yang dihadapi oleh siswa yang bersangkutan. Ketercapaian perkembangan siswa diperlukan tiga komponen pokok : 1) program kurikulum; 2) administrasi, 3) bimbingan belajar yang terarah. Ketiga komponen tersebut merupakan satu kesatuan yang integral.

Bimbingan di sekolah, sangat diperlukan guna membantu siswa dalam mengatasi permasalahannya, dalam masalah belajar atau masalah pribadi siswa. (Pedoman BP.SD, 1994 ). Bimbingan siswa harus memiliki prinsip dasar yang kuat sebagai landasan pelaksanaannya, sehingga layanan kelompok belajar merupakan salah satu program yang 
harus dilaksanakan di sekolah. Sekolah merupakan salah satu sistem pendidikan, dihadapkan pada tugas pokok untuk meningkatkan kehidupan yang lebih baik, kecerdasan, ketrampilan serta budi pekerti yang luhur merupakan unsur daripada tujuan pendidikan di sekolah. Guru berkewajiban untuk memberikan layanan kelompok belajar pada kesulitan yang sangat mendasar. Maka motivasi dalam belajar siswa itu sangat diperhatikan, sehingga dalam Kegiatan belajar megnajar siswa mampu menyerap ilmu yang disampaiakan. Motiviasi merupakan sebuah titik awal dalam membuka kemampuan siswa yang sebenarnya berpotensi besar untuk berhasil. Maka motivasi ini perlu ditumbuh kembangkan dan di dorong dari diri siswa.

Dari latar belakang terbsebut akhirnya penulis mengambil sebuah judul penelitian " Implementasi Layanan Konseling dengan Methode Reinforcement Guna Meningkatkan Motivasi Belajar Pada Siswa Kelas XI IPA 3 SMA Negeri 5 Kota Jambi Tahun Pelajaran 2017/2018. Adapun yang menjadi tujuan penelitian ini adalah 1) untuk mengungkap pengaruh metode Reinforcemen terhadap motivasi belajar siswa SMA N 5 Kota Jambi Kelas XI IPA 3 tahun pelajaran 2017/2018, dan 2) ingin mengetahui seberapa jauh kreatifitas siswa dalam belajar setelah diterapkannya metode Reinforcemen pada siswa sekolah SMA N 5 Kota Jambi Kelas XI IPA 3 tahun pelajaran $2017 / 2018$

\section{Kajian Teori \\ Bimbingan dan Konseling}

Menurut Prayitno (2008) bimbingan adalah layanan yang diberikan kepada klien agar bisa membantu dalam menyelesaikan masalah. Gazda dalam bukunya Prayitno mengemukakan bahwa bimbingan kelompok di sekolah merupakan kegiatan informasi kepada siswa untuk membantu mereka menyusun rencana dan keputusan yang tepat. Selanjutnya menurut Gammon (dalam Ahmadi, 2009) bimbingan adalah usaha membantu peserta didik agar dapat sebanyak mungkin memetik manfaat dari pengalaman -pengalaman yang mereka dapatkan selama berada di sekolah. Bimbingan di sekolah meliputi harapan-harapan yang menyangkut perkembangan pendidikan, perkembangan sosial dan sedapat mungkin diorientasikan pada bidang akademis.

Sukardi (2008) berpendapat bahwa bimbingan adalah layanan bimbingan yang memungkinkan sejumlah peserta didik secara bersama-sama memperoleh berbagai bahan dari narasumber tertentu (terutama dari pembimbing/konselor) yang berguna untuk menunjang kehidupannya sehari -hari baik individu maupun sebagai pelajar, anggota keluarga dan masyarakat serta untuk pertimbangan dalam pengambilan keputusan.

Disisi lain definisi konseling menurut Ahmad (2006) merupakan bantuan kepada individu yang bersifat pencegahan dan penyembuhan, serta diarahkan pada pemberian kemudahan dalam perkembangan dan pertumbuhannya. Menurut Latipun (2006) konseling adalah pemberian bantuan dengan memanfaatkan suasana hati klen untuk membantu, memberi umpan balik (feedback) dan pengalaman belajar. Lebih lanjut Prayitno (2008) memberikan rumusan tentang konseling adalah memberikan bantuan melalui interaksi sosial klien sesuai dengan setiap kebutuhan individu. Konseling menurut Winkel (2004) adalah suatu kegiatan bimbingan yang memiliki ciri -ciri khas yaitu kombinasi dari bentuk "individu" dengan aktivitas "pembahasan suatu masalah".

Menurut pendapat Ohlsen (dalam Sukardi, 2008) konseling adalah suatu hubungan antara konselor dengan satu atau lebih klien yang penuh perasaan penerimaan, kepercayaan dan rasa aman. Sedangkan menurut Sukardi (2008) memberikan pengertian konseling adalah bimbingan dan konseling yang memungkinkan peserta didik memperoleh kesempatan untuk pembahasan dan pengentasan permasalahan yang dialaminya melalui dinamika sosial.

Dari uraian pengertian bimbingan dan konseling diatas dapat disimpulkan bahwa bimbingan adalah layanan yang di berikan kepada seseorang atau klien dengan pemberian informasi untuk keperluan tertentu. Sedangkan konseling adalah pemberian bantuan dan informasi yang bersifat pencegahan, penyembuhan sesuai dengan kebutuhan setiap individu atau kelompok.

Selain memahami tentang pengertian bimbingan dan konseling, pemahaman akan prinsip bimbingan konseling, fungsi bimbingan konseling, dan tujuan konseling perlu juga dibahas dalam kajian teori ini agar lebih mendalam memahami apa yang menjadi tujuan dari penelitian ini. Adapun prinsip-prinsip bimbingan konseling menurut Sukardi (2008) terbagi menjadi dua bagian yakni prinsip umum dan prinsip khusus. Dimana, prinsip umum bimbingan konseling diantaranya sebagai berikut:

a. Karena bimbingan itu berubungan dengan sikap dan tingkah laku individu,

b. perlulah diingat bahwa sikap dan tingkah laku itu terbentuk dari segala aspek kepribadian yang unik dan ruwet.

c. Perlu dikenal dan dipahami perbeadan individu daripada individu -individu

d. yang dibimbing, ialah untuk memberikan bimbingan yang tepat sesuai dengan apa yang dibutuhkan oleh individu yang bersangkutan.

e. Bimbingan harus berpusat pada individu yang dibimbing

f. Masalah yang tidak dapat diselesaikan di sekolah harus diserahkan kepada individu atau lembaga yang mampu dan berwenang melakukannya 
g. Bimbingan harus dimulai dengan identifikasi kebutuhan kebutuhan yang

h. dirasakan oleh individu yang dibimbing

i. Bimbingan harus fleksibel sesuai dengan kebutuhan individu dan masyarakat

j. Program bimbingan harus sesuai dengan program pendidikan di sekolah yang bersangkutan

k. Pelaksanaan program bimbingan harus dipimpin oleh seorang petugas yang memiliki keahlian dalam bidang bimbingan dan sanggup bekerja sama dengan para pembantunya serta dapat dan bersedia mempergunakan sumbersumber yang berguna diluar sekolah

1. Terhadap program bimbingan harus senantiasa diadakan penilaian teratur untuk mengetahui sampai dimana hasil dan manfaat yang diperoleh serta penyesuaian antara pelaksanaan dan rencana dirumuskan terahulu.

Sedangkan untuk prinsip yang khusus meliputi 1) bimbingan konseling melayani semua individu tanpa memandang umur, jenis kelamin, suku, agama dan status sosial ekonomi, 2) bimbingan konseling berurusan dengan pribadi dan tingkah laku individu yang unik dan dinamis, 3) bimbingan konseling memperhatikan sepenuhnya tahap dan berbagai aspek perkembangn individu, dan 4) bimbingan konseling memberikan perhatian utama kepada perbedaan individual yang menjadi orientasi pokok pelayanan.

Selanjutnya fungsi dari bimbingan dan konseling menurut Sukardi (2008) diantaranya: 1) menyalurkan, ialah fungsi bimbingan dalam membantu siswa mendapatkan lingkungan sesuai dengan keadaan dirinya, 2) mengadaptasikan, ialah fungsi bimbingan dalam membantu siswa di sekolah mengadaptasikan program pemdidikan dengan keadaan masing-masing siswa, 3) menyesuaikan, ialah fungsi bimbingan dalam rangka membantu siswa menyesuaikan diri dengan lingkungan sekolah, 4) pencegahan, ialah fungsi bimbingan dalam rangka membantu siswamenghindari kemungkinan terjadinya hambatan, 5) perbaikan, ialah fungsi bimbingan dalam rangka membantu siswauntuk memperbaiki kondisi siswa yang dipandang kurang memadai, 6) pengembangan, ialah fungsi bimbingan dalam rangka membantu siswa untuk melampaui proses dan fase perkembangan secara wajar, 7) bergerak lebih jauh dengan melihat harapan -harapan yang ingin di capai, dan 8) menjelaskan nilai dan menentukan apakah dan bagaimana mengubah nilai tersebut.

Adapun tujuan dari bimbingan konseling menurut Winkel (2004) dibagi menjadi dua yaitu tujuan sementara dan tujuan akhir. Tujuan sementara adalah supaya orang bersikap dan bertindak sendiri dalam situasi hidupnya sekarang ini. Tujuan akhir adalah supaya orang mampu mengatur kehidupanya sendiri, mengambil keputusan sendiri, mempunyai pandangan hidup sendiri dan menanggung resiko atau konsekuensi dari tindakan-tindakannya.

Menurut Sukardi (2008) tujuan dari program layanan bimbingan konseling diantaranya: 1) mengembangkan pengertian dan pemahaman diri siswa dalam kemajuan dirinya di sekolah, 2) memilih dan mempertemukan pengetahuan tentang dirinya denganinformasi dengan kesempatan yang ada secara tepat dan bertanggung jawab, 3) mewujudkan penghargaan terhadap diri orang lain, 4) mengatasi kesulitan dalam memahami dirinya, 5) memahami lingkungan sekolah, keluarga dan masyaraka, dan 6) mengidentifikasikan dan mengatasi masalah yang dihadapinya. Sedangkan untuk tujuan bimbingan konseling yang terkait dengan tujuan teoritis konseling secara lengkap dikemukakan Corey (dalam Latipun, 2006) adalah sebagai berikut:

a. Belajar percaya pada diri sendiri dan orang lain.

b. Mengetahui keunikan diri sendiri dan mngembangkannya.

c. Mengenal anggota yang lain dan mengembangkan kebutuhan serta masalah yang dihadapi.

d. Menambah penerimaan diri, kepercayaan diri individu.

e. Menemukan cara alternatif, pengembangan persoalan, pemecahkan perselisihan dan salah paham.

f. Menciptakan tanggung jawab sendiri dan orang lain

g. Membuat pilihan atau keputusan secara bijaksana.

h. Membuat rencana khusus untuk masalah perubahan tingkah laku.

i. Belajar berinteraksi sosial secara efektif.

j. Menjadikan lebih sensitif dan merasakan masalah anggota lainnya.

k. Belajar menghadapi masalah dengan peduli, keprihatinan, ketulusan hati dan pemberian solusi.

\section{Pembahasan Tentang Penguatan (Reinforcement)}

Dalam proses belajar mengajar, penghargaan atau pujian terhadap perbuatan yang baik dari siswa merupakan hal sangat diperlukan sehingga siswa terus berusaha berbuat lebih baik misalnya guru tersenyum atau mengucapkan kata-kata bagus kepada siswa yang dapat mengerjakan pekerjaan rumah yang baik akan besar pengaruhnya terhadap siswa. Siswa tersebut akan merasa puas dan merasa diterima atas hasil yang dicapai, dan siswa lain diharapkan akan berbuat seperti itu.

Menurut Soemanto (2012) yang dimaksud dengan pemberian penguatan (reinforcement) adalah suatu respon positif dari guru kepada siswa yang telah melakukan suatu perbuatan yang baik atau berprestasi. Pemberian penguatan (reinforcement) ini dilakukan oleh guru dengan tujuan agar siswa dapat lebih giat berpartisipasi dalam interaksi belajar 
mengajar dan mengajar dan siswa agar mengulangi lagi perbuatan yang baik itu. Sedangkan menurut Usman (2005) penguatan (Reinforcement) adalah segala bentuk respon, apakah bersifat verbal ataupun nonverbal, yang merupakan bagian dari modifikasi tingkah laku guru terhadap tingkah laku siswa, yang bertujuan untuk memberikan informasi atau umpan balik (feet back) bagi sipenerima (siswa) atas perbuatannya sebagai suatu tindakan dorongan ataupun koreksi. Penguatan dikatakan juga sebagai respon terhadap tingkah laku yang dapat meningkatkan kemungkinan berulangnya tingkah laku tersebut. Tindakan tersebut dimaksudkan untuk mengganjar atau membesarkan hati siswa agar mereka lebih giat berpartisipasi untuk interaksi dalam belajar mengajar.

Tujuan pemberian penguatan itu sendiri untuk merangsang motivasi siswa lebih giat dalam belajar, seperti yang dikemukakan oleh Mulyasa (2011) ada tiga tujuan pemberian penguatan yaitu: 1) meningkatkan perhatian siswa terhadap pembelajaran, 2) merangsang dan meningkatkan motivasi belajar, dan 3) meningkatkan kegiatan belajar dan membina prilaku laku yang produktif. Sedangkan menurut Hasibuan dan Moedjiono (2010) ada beberapa tujuan pemberian penguatan diantaranya:1) meningkatkan perhatian siswa terhadap pembelajarn, 2) melancarkan atau memudahkan proses belajar, 3) mengontrol atau mengubah sikap yang mengganggu kearah tingkah laku belajar yang produktif, 4) mengembangkan dan mengatur diri sendiri dalam belajar, dan 5) mengarahkan kepada cara berfikir yang baik atau divergen dan inisiatif sendiri.

Selanjutnya Usman (2005) mengemukakan dua macam pemberian penguatan, yaitu verbal dan non verbal. Kedua macam pengutan tersebut dapat dijelaskan sebagai berikut:

1. Penguatan verbal. Penguatan ini biasanya diungkapkan dengan menggunakan kata-kata pujian, penghargaan, persetujuan dan sebagainya.

2. Penguatan nonverbal. Pengutan ini dapat dilakukan dengan berbagai cara, antara lain: a) penguatan gerak isyarat, misalnya anggukan, senyuman, acungan jempol wajah cerah dan masih banyak yang lainya, b) penguatan pendekatan, dan c) penguatan dengan sentuhan.

Pemberian penguatan (reinforcement) sifatnya sederhana dalam pelaksanaannya, namun dapat pula pemberian penguatan (reinforcement) yang diberikan pada siswa enggan belajar, karena penguatan yang diberikan tidak sesuai dengan yang dikehendaki siswa. Dalam pemberian penguatan (reinforcement) yang penting harus sesuai dengan tindakan yang dilakukan oleh siswa tersebut, pemberian penguatan yang berlebihan akan berakibat fatal. Untuk itu maka guru harus memperhatikan prinsip-prinsip dalam pemberian penguatan. Menurut Moh. Uzer Usman ada tiga prinsip dalam penggunaan penguatan, yaitu:

1. Kehangatan dan keantusiasan

Sikap dan gerak guru, termasuk suara, mimik, dan gerak badan akan menunjukkan adanya kehangatan dan keantusiasan dalam memberikan penguatan.

2. Kebermaknaan

Penguatan hendaknya diberikan sesuai dengan tingkah laku dan penampilan siswa sehingga ia mengerti dan yakin bahwa ia patut diberi penguatan.

3. Menghindari penggunaan respons yang negatif

Respon negatif yang diberikan oleh guru terhadap siswa akan mematahkan semangat siswa dalam mengembangkan dirinya.

\section{Tinjauan Tentang Motivasi Belajar}

Motivasi belajar terdiri dari dua kata yang mempunyai pengertian sendiri-sendiri yaitu motivasi dan belajar, namun dalam pembahasan ini dua kata yang berbeda tersebut saling berhubungan membentuk satu arti. Untuk lebih jelasnya penulis akan memaparkan pengertian dua kata tersebut. Motivasi berasal dari dari kata motif, kata motif diartikan sebagai upaya yang mendorong seseorang untuk melakukan sesuatu. Motif dapat dikatakan sebagai daya penggerak dari dalam dan didalam subyek untuk melakuakan aktivitas-aktivitas tertentu demi mencapai suatu tujuan. Berawal dari kata motif itu maka motivasi dapat diartikan sebagai daya penggerak yang telah menjadi aktif.

Motivasi merupakan segala tenaga yang dapat membangkitkan atau mendorong seseorang untuk melakukan suatu perbuatan. Jadi secara etimologi motivasi adalah dorongan atau daya penggerak yang dapat membangkitkan atau mendorong seseorang untuk melakukan suatu tindakan dalam rangka mencapai tujuan. Secara terminologi, banyak para ahli yang memberikan batasan tentang pengertian motivasi (dalam Makmun, 2012) antara lain sebagai berikut:

1) Mc. Donald mengemukakan bahwa motivasi adalah suatu perubahan energi di dalam pribadi seseorang yang ditandai dengan timbulnya afetif dan reaksi untuk mencapai tujuan.

2) Clifford T. Morgan menjelaskan bahwa motivasi bertalian dengan tiga hal yang sekaligus merupakan aspek-aspek dari motivasi yaitu keadaan yang mendorong (motivating states), tingkah laku yang didorong oleh keadaan tersebut (motivated behavior), dan tujuan dari tingkah laku tersebut (goals or end such behavior).

3) James O. Whittaker, memberikan pengertian tentang motivasi sebagai kondisi atau keadaan yang mengaktifkan atau memberi dorongan kepada makhluk untuk bertingkah laku mencapai tujuan yang ditimbulkan oleh motivasi. 
Selma Br Hutabarat, Implementasi Layanan Konseling dengan Methode Reinforcement Guna Meningkatkan Motivasi Belajar Pada Siswa Kelas XI IPA 3 SMAN 5 Kota Jambi Tahun Pelajaran 2014/2015 berikut:

Lebih lanjut pengertian belajar dapat didefinisikan menurut beberapa para ahli (dalam Makmun, 2012) sebagai

1) HC. Witherington memberi batasan belajar adalah perubahan di dalam kepribadian yang menyatukan sebagai suatu pola baru dari reaksi yang berupa kecakapan, sikap, kebiasaan, kepandaian atau suatu pengertian.

2) Morgan mengemukakan bahwa belajar adalah setiap perubahan yang relatif menetap dalam tingkah laku yang terjadi sebagai suatu hasil dari latihan atau pengalaman.

3) Lester D. Crow mengemukakan belajar adalah upaya untuk memperoleh kebiasaan-kebiasaan, pengeahuan dan sikap-sikap.

4) Menurut Makmun (2012) yang dimaksud dengan perubahan dalam konteks belajar itu dapat bersifat fungsional atau struktural, material, dan behavioral, serta keseluruhan pribadi.

Dari pengertian motivasi dan belajar yang dikemukakan di atas, dapat diambil kesimpulan bahwa motivasi belajar adalah totalitas daya penggerak psikis dalam diri siswa yang menimbulkan kegiatan belajar dan memberi arah pada kegiatan belajar untuk mencapai tujuan. Dalam hal ini Sardiman (2011) mengemukakan bahwa dalam kegiatan belajar motivasi dapat dikatakan sebagai keseluruhan daya penggerak dalam diri siswa yang menimbulkan kegiatan belajar sehingga tujuan yang dikehendaki oleh subjek belajar dapat tercapai, sehingga perubahan prilaku dalam belajar relatif permanen.

Beberapa uraian diatas dapat dipahami bahwa motivasi belajar memegang peranan penting, sebab motivasi akan memberikan gairah atau semangat seseorang (siswa) dalam belajar sehingga siswa akan memiliki energi yang banyak untuk melakukan kegiatan belajar demi mencapai tujuan. Adapun ciri-ciri anak yang termotivasi dalam melaksanakan kegiatan belajar mengajarnya menurut Sardiman (2011) adalah: 1) tekun menghadapi tugas, 2) ulet menghadapi kesulitan, 3) menunjukkan minat terhadap macam-macam masalah, 4) lebih senang belajar mendiri, 5) cepat bosan dengan tugas rutin (kurang kreatif), 6) sering mencari dan memecahkan soal-soal, 7) tidak mudah melepaskan hal-hal yang sudah diyakini, dan 8) dapat mempertahankan pendapatnya.

Apabila seorang anak memiliki ciri-ciri diatas berarti dia telah memiliki motivasi yang kuat dalam melaksanakan proses belajr mengajar. Ciri-ciri tersebut penting karena dengan motivasi yang kuat anak akan bisa belajar dengan baik, lebih mandiri dan tidak terjebak pada sesuatu yang rutinitas dan mekanis. Ciri seorang siswa yang mempunyai motivasi tinggi adalah mereka sangat semangat untuk mencapai tujuannya dan tidak mudah menyerah, sebelum mendapatkan apa yang inginkan. Siswa mempertahankan pendapatnya, kalau ia sudah yakin dan dipandangnya cukup rasional. Bahkan lebih lanjut siswa harus juga peka dan responsive terhadap berbagai masalah umum, dan bagaimana memikirkan pemecahannya.

\section{METODE}

Penelitian ini merupakan penelitian tindakan (action research), karena penelitian dilakukan untuk memecahkan masalah pembelajaran di kelas. Menurut McNeiff (2002): action research is a term which refer to a practical way of looking at your own work to sheck that it is you would like it to be. Because action researchis done by you, the practitioner, it is often referred to as practitioner based research; and because it involves you thinking about and reflecting on your work, it can also be called a form of self-reflective practice. Penjelasan McNeiff tersebut, dapat dicermati pengertian PTK secara lebih rinci dan lengkap. PTK didefinisikan sebagai suatu bentuk kajian yang bersifat reflektif oleh pelaku tindakan. Tindakan tersebut dilakukan untuk meningkatkan kemantapan rasional dari tindakantindakan mereka dalam melaksanakan tugas sehari-hari, memperdalam pemahaman terhadap tindakan-tindakan yang dilakukan, serta memperbaiki kondisi di mana praktik-praktik pembelajaran tersebut dilakukan. Untuk mewujudkan tujuan-tujuan tersebut, PTK dilaksanakan dalam proses berdaur (cyclical) yang terdiri dari empat tahapan, planing, action, observation/evaluation, dan reflection.

Dalam penelitian tindakan ini menggunakan bentuk guru sebagai peneliti, penanggung jawab penuh penelitian ini adalah guru. Tujuan utama dari penelitian tindakan ini adalah untuk meningkatkan hasil pembelajaran di kelas dimana guru secara penuh terlibat dalam penelitian mulai dari perencanaan, tindakan, pengamatan, dan refleksi. Tempat penelitian di SMA N 5 Kota Jambi, dan yang menjadi subyek penelitian adalah siswa-siswi Kelas XI IPA 3 tahun pelajaran 2017/2018. Penelitian ini menggunakan model penelitian tindakan dari Kemmis dan Taggart (dalam Sugiarti, 1997), yaitu berbentuk spiral dari siklus yang satu ke siklus yang berikutnya. Setiap siklus meliputi planning (rencana), action (tindakan), observation (pengamatan), dan reflection (refleksi). Langkah pada siklus berikutnya adalah perncanaan yang sudah direvisi, tindakan, pengamatan, dan refleksi. Sebelum masuk pada siklus 1 dilakukan tindakan pendahuluan yang berupa identifikasi permasalahan. Siklus spiral dari tahap-tahap penelitian tindakan kelas dapat dilihat pada gambar berikut: 


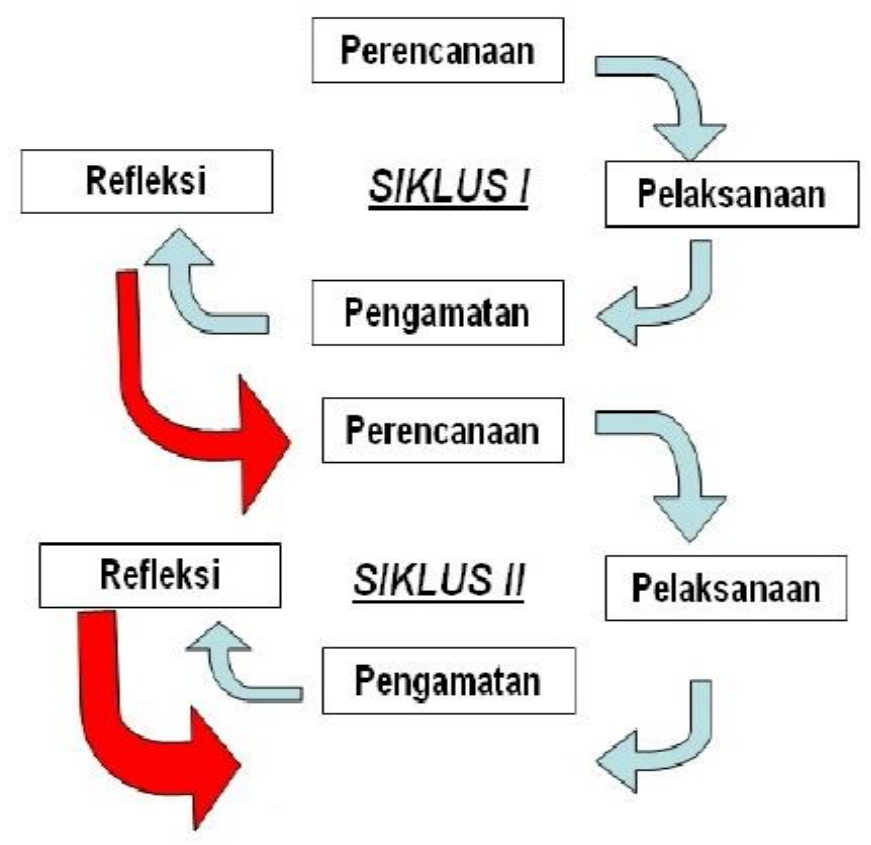

\section{Gambar 1. Alur PTK}

Penelitian ini dilakukan dengan metode penelitian tindakan sekolah yang berlangsung selama 2 siklus. Masingmasing siklus terdiri dari tahapan perencanaan, pelaksanaan, observasi dan refleksi. Metode penelitian yang dilakukan peneliti adalah dengan melaksanakan Penerapan Pengawasan Melekat yang meliputi supervise tradisional dan supervise klinis yang secara rinci dapat diuraikan sebagai berikut:

1. Perencanaan Awal

Langkah awal yang direncanakan pada penilitian tindakan sekolah ini terdiri dari beberapa kegiatan, yakni:

a. Identifikasi masalah

b. Pengajuan proposal

c. Mempersiapkan instrument

2. Siklus pertama.

a. Perencanaan

Pada tahap ini, peneliti merencanakan langkah-langkah sebagi berikut:

1) Mengidentifikasi jumlah siswa dalam kelas.

2) Meminta siswa mengisi instrumen layanan.

3) Peneliti memeriksa nilai dan kegiatan KBM

4) Peneliti mengidentifikasi permasalahan yang ditemukan.

5) Menyusun rencana

b. Pelaksanaan

Pada tahap ini peneliti melaksanakan rencana tindakan berupa layanan konseling pada siswa. Peneliti memberikan instrumen penelitian berupa pertanyaan dan isian yang harus dijawab siswa.

c. Observasi

Pada tahap ini peneliti melakukan kegiatan observasi terhadap seluruh kejadian yang terjadi selama tahap pelaksanaan dan mengobservasi hasil awal yang dicapai pada pelaksanaan tindakan siklus 1 . Selain itu peneliti juga mengidentifikasi masalah-masalah lanjutan yang timbul dari pelaksanaan tindakan di siklus 1 .

d. Refleksi

Pada tahap refleksi, peneliti melakukan evaluasi terhadap tindakan dan data-data yang diperoleh. Kemudian dilanjutkan dengan pertemuan bersama kolaborator untuk membahas hasil evaluasi dan penyusunan langkahlangkah untuk siklus kedua.

3. Siklus kedua

a. Perencanaan

Pada tahap ini, peneliti merencanakan langkah-langkah sebagi berikut: 
1) Mengidentifikasi jumlah siswa dalam kelas.

2) Meminta siswa mengisi instrumen layanan.

3) Peneliti memeriksa nilai dan kegiatan KBM

4) Peneliti mengidentifikasi permasalahan yang ditemukan.

5) Menyusun rencana

b. Pelaksanaan

Pada tahap ini peneliti melaksanakan rencana tindakan berupa layanan konseling pada siswa. Peneliti memberikan instrumen penelitian berupa pertanyaan dan isian yang harus dijawab siswa.

c. Observasi

Di tahap observasi siklus kedua, peneliti mengobservasi kesesuaian perencanaan pembelajaran dengan pelaksanaan pembelajaran serta melihat keberterimaan siswa dalam proses belajar mengajar. Pada tahap ini pula, peneliti mengumpulkan data-data yang terjadi selama tahap pelaksanaan.

d. Refleksi

Pada tahap refleksi, peneliti melakukan evaluasi terhadap tindakan dan data-data yang diperoleh. Kemudian dilanjutkan dengan pertemuan bersama kolaborator untuk membahas hasil evaluasi.

Pada penelitian ini menggunakan teknik analisa deskriptif kuantitatif, yaitu suatu metode penelitian yang bersifat menggambarkan kenyataan atau fakta sesuai dengan data yang diperoleh dengan tujuan untuk mengetahui prestasi belajar yang dicapai siswa juga untuk memperoleh respon siswa terhadap kegiatan pembelajaran serta aktivitas siswa selama proses pembelajaran. Untuk menganalisis tingkat keberhasilan atau persentase keberhasilan siswa setelah proses belajar mengajar setiap putarannya dilakukan dengan cara memberikan evaluasi berupa tes praktek pada setiap akhir putaran, Analisa ini dihitung dengan menggunakan statistic sederhana yaitu:

1. Untuk menilai tes praktek

Peneliti melakukan penjumlahan nilai yang diperoleh siswa yang selanjutnya dibagi dengan jumlah siswa yang ada di kelas tersebut sehingga diperlukan rata-rata tes praktek dapat dirumuskan

$$
\bar{X}=\frac{\sum X}{\sum N}
$$

Dengan:

$$
\begin{array}{ll}
\bar{X} & =\text { Nilai rata-rata } \\
\sum X & =\text { Jumlah semua nilai siswa } \\
\sum N & =\text { Jumlah siswa }
\end{array}
$$

2. Untuk Ketercapaian belajar

Ada dua kategori Ketercapaian belajar yaitu secara perorangan dan secara klasikal. Berdasarkan petunjuk pelaksanaan belajar mengajar kurikulum 1994 (Depdikbud, 1994) yaitu siswa telah tuntas belajar bila di kelas tersebut mendapat $85 \%$ yang telah mencapai daya serap dari sama dengan. Untuk menghitung persentase Ketercapaian belajar digunakan rumus sebagai berikut:

$$
P=\frac{\sum \text { Siswayangtuntasbelajar }}{\sum \text { siswa }} \times 100 \%
$$

3. Untuk lembar observasi

a. Lembar observasi pengolahan metode penampilan dan eksperimen. Untuk menghitung lembar observasi pengolahan metode penampilan dan eksperimen digunakan rumus sebagai berikut:

$$
\bar{X}=\frac{P_{1}+P_{2}}{2}
$$

Dimana:

$$
\begin{array}{ll}
\mathrm{P}_{1} & =\text { pengamatan } 1 \\
\mathrm{P} 2 & =\text { pengamat } 2
\end{array}
$$

b. Lembar observasi aktivitas guru dan siswa. Untuk menghitung lembar observasi aktivitas guru dan siswa digunakan rumus sebagai berikut:

$$
\%=\frac{\bar{X}}{\sum X} x 100 \% \text { dengan }
$$




$$
\bar{X}=\frac{\text { jumlahhasilpengama } \tan }{\text { jumlahpengamat }}=\frac{P_{1}+P_{2}}{2}
$$

Dimana:

$$
\begin{array}{ll}
\frac{\%}{X} & =\text { Persentase angket } \\
\sum \bar{X} & =\text { Rata-rata } \\
\mathrm{P}_{1} & =\text { Pengamat } 1 \\
\mathrm{P}_{2} & =\text { Pengamat } 2
\end{array}
$$

Untuk menghitung persentase angket digunakan rumus sebagai berikut:

$$
P=\frac{Z}{n}
$$

Dimana

$\mathrm{P} \quad=$ Persentase

$\mathrm{Z} \quad=$ Alternatif jawaban $(\mathrm{A}, \mathrm{B}, \mathrm{C}, \mathrm{D})$

$\mathrm{n} \quad=$ Jumlah responden

c. Aspek yang diamati adalah ranah psikomotor. Mengadakan analisis terhadap data hasil pengamatan yanbg menggunakan rating scale, hal ini dimaksudkan apakah penelitian bisa dihentikan atau dilanjutkan pada siklus berikutnya. Skala peniloaian yang digunakan sesuai dengan instrument yang telah direncanakan, yaitu antara 13 ( $1=$ kurang tepat, $2=$ cukup dan $3=$ tepat) untuk aspek penilaian. Hal ini berarti bahwa:

- Skor minima yang diperoleh siswa adalah: 1 x $4=4$

- Skor maksimal yan diperoleh siswa adalah: 3 x $4=12$

- Medium skor adalah : $\frac{(4+12)}{2}=8$

- Dibuat rentang skor dan dikonversi menjadi nilai rapor sebagai pedoman penilaian.

Tabel 1. Pedoman Penilaian Ranah psikomotor

\begin{tabular}{llll}
\hline No & Rentang skor & Nilai Rapor & Predikat \\
\hline 1 & $11-12$ & A & Baik sekali \\
2 & $9-10$ & B & Baik \\
3 & $7-8$ & C & Cukup \\
4 & $5-6$ & K & Kurang \\
5 & $3-4$ & KS & Kurang sekali \\
\hline
\end{tabular}

Mutu Pembelajaran dikatakan baik apabila siswa yang mendapat nilai diatas 70 mencapai $85 \%$ atau lebih dari keseluruhan siswa

\section{HASIL DAN PEMBAHASAN}

Siklus I

Tahap Perencanaan

Pada tahap ini peneliti mempersiapkan pembelajaran yang terdiri dari rencana pelajaran 1, soal tes 1 dan alatalat pengajaran yang mendukung. Selain itu juga dipersiapkan lembar observasi dan aktivitas siswa.

\section{Tahap kegiatan dan Pelaksanaan}

Pelaksanaan kegiatan belajar mengajar untuk siklus I dilaksanakan pada tanggal 6 September 2017 di Kelas XI IPA 3 dengan jumlah siswa 40 siswa. Adapun proses belajar mengajar mengacu pada rencana pelajaran yang telah dipersiapkan. Pengamatan (observasi) dilaksanakan bersamaan dengan pelaksanaan belajar mengajar. Pada akhir proses belajar mengajar siswa diberi tes I dengan tujuan untuk mengetahui keberhasln siswa dalam proses layanan konseling yang telah dilakukan. Adapun data hasil penelitian pada siklus I adalah sebagai berikut: 
Selma Br Hutabarat, Implementasi Layanan Konseling dengan Methode Reinforcement Guna Meningkatkan Motivasi Belajar Pada Siswa Kelas XI IPA 3 SMAN 5 Kota Jambi Tahun Pelajaran 2014/2015

Tabel 2. Hasil Penelitian Pada Siklus I

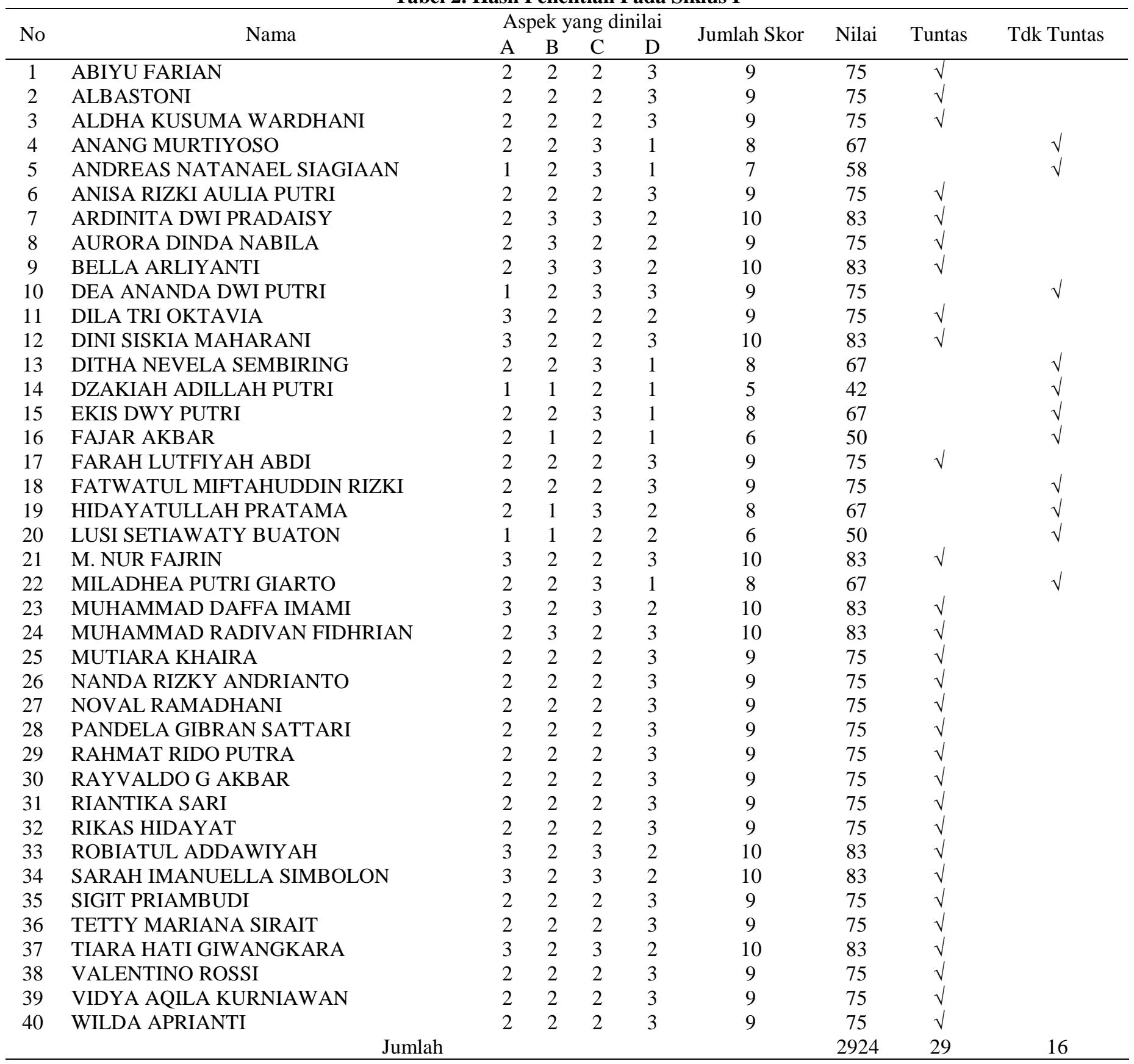

Jumlah seharusnya $=4000$

Jumlah yang diperoleh $=2924$

Rata-rata $=74$

Prosentase $=72 \%$

Keterangan:

a. Tekun menghadapi tugas serta ulet menghadapi kesulitan.

b. Menunjukkan minat terhadap macam-macam masalah dan mencoba belajar mandiri.

c. Sering mencari dan memecahkan soal-soal.

d. Tidak mudah melepaskan hal-hal yang sudah diyakini serta dapat mempertahankan pendapatnya.

Dari tabel di atas jelas terlihat bahwa siswa yang nilai skor diatas minimal (75) adalah sebesar $72 \%$.

\section{Refleksi}

Dalam pelaksanaan kegiatan belajar mengajar diperoleh informasi dari hasil pengamatan sebagai berikut:

1. Guru kurang baik dalam memotivasi siswa dan dalam menyampaikan layanan konseling.

2. Guru kurang baik dalam pengelolaan waktu

3. Siswa kurang bisa antusias selama layanan. 
Revisi

Pelaksanaan kegiatan layanan konseling pada siklus I ini masih terdapat kekurangan, sehingga perlu adanya revisi untuk dilakukan pada siklus berikutnya.

1. Guru perlu lebih terampil dalam memotivasi siswa dan lebih jelas dalam menyampaikan tujuan pembelajaran. Dimana siswa diajak untuk terlibat langsung dalam setiap kegiatan yang akan dilakukan.

2. Guru perlu mendistribusikan waktu secara baik dengan menambahkan informasi-informasi yang dirasa perlu dan memberi catatan.

3. Guru harus lebih terampil dan bersemangat dalam memotivasi siswa sehingga siswa bisa lebih antusias.

\section{Siklus II}

Tahap perencanaan

Pada tahap ini peneliti mempersiapkan pembelajaran yang terdiri dari rencana layanan konseling 2 , soal tes 2 dan alat-alat pengajaran yang mendukung. Selain itu juga dipersiapkan lembar observasi dan aktivitas siswa.

\section{Tahap kegiatan dan pelaksanaan}

Pelaksanaan kegiatan belajar mengajar untuk siklus II dilaksanakan pada tanggal 6 September 2017 di Kelas XI IPA 3 dengan jumlah siswa 40 siswa. Dalam hal ini peneliti bertindak sebagai pengajar. Adapun proses belajar mengajar mengacu pada rencana pelajaran dengan memperhatikan revisi pada siklus I, sehingga kesalahan atau kekuarangan pada siklus I tidak terulang lagi pada siklus II. Pengamatan (observasi) dilaksanakan bersamaan dengan pelaksanaan belajar mengajar. Sebagai pengamat adalah peneliti dibantu oleh seorang guru Reflina, S.Pd. Pada akhir proses belajar mengajar siswa diberi tes Psikomotor II dengan tujuan untuk mengetahui tingkat keberhasilan siswa dalam proses belajar mengajar yang dilakukan. Instrument yang digunakan adalah tes praktek II. Adapun data hasil penelitian pada siklus II adalah sebagai berikut:

Tabel 3. Hasil Penelitian pada Siklus II

\begin{tabular}{|c|c|c|c|c|c|c|c|c|c|}
\hline \multirow{2}{*}{ No } & \multirow{2}{*}{ Nama } & \multicolumn{4}{|c|}{ Aspek yang dinilai } & \multirow{2}{*}{ Jumlah Skor } & \multirow{2}{*}{ Nilai } & \multirow{2}{*}{ Tuntas } & \multirow{2}{*}{ Tdk Tuntas } \\
\hline & & A & $\mathrm{B}$ & $\mathrm{C}$ & $\mathrm{D}$ & & & & \\
\hline 1 & ABIYU FARIAN & 2 & 3 & 3 & 3 & 11 & 92 & $\sqrt{ }$ & \\
\hline 2 & ALBASTONI & 2 & 2 & 2 & 3 & 9 & 75 & $\sqrt{ }$ & \\
\hline 3 & ALDHA KUSUMA WARDHANI & 2 & 2 & 2 & 3 & 9 & 75 & $\sqrt{ }$ & \\
\hline 4 & ANANG MURTIYOSO & 2 & 2 & 2 & 3 & 9 & 75 & $\sqrt{ }$ & \\
\hline 5 & ANDREAS NATANAEL SIAGIAAN & 3 & 2 & 3 & 3 & 11 & 92 & $\sqrt{ }$ & \\
\hline 6 & ANISA RIZKI AULIA PUTRI & 2 & 2 & 2 & 3 & 9 & 75 & $\sqrt{ }$ & \\
\hline 7 & ARDINITA DWI PRADAISY & 2 & 3 & 3 & 2 & 10 & 83 & $\sqrt{ }$ & \\
\hline 8 & AURORA DINDA NABILA & 2 & 3 & 2 & 2 & 9 & 75 & $\sqrt{ }$ & \\
\hline 9 & BELLA ARLIYANTI & 2 & 3 & 3 & 2 & 10 & 83 & $\sqrt{ }$ & \\
\hline 10 & DEA ANANDA DWI PUTRI & 3 & 3 & 3 & 3 & 12 & 100 & $\sqrt{ }$ & \\
\hline 11 & DILA TRI OKTAVIA & 3 & 2 & 2 & 2 & 9 & 75 & $\sqrt{ }$ & \\
\hline 12 & DINI SISKIA MAHARANI & 3 & 2 & 2 & 3 & 10 & 83 & $\sqrt{ }$ & \\
\hline 13 & DITHA NEVELA SEMBIRING & 2 & 2 & 3 & 2 & 9 & 75 & $\sqrt{ }$ & \\
\hline 14 & DZAKIAH ADILLAH PUTRI & 2 & 2 & 2 & 3 & 9 & 75 & $\sqrt{ }$ & \\
\hline 15 & EKIS DWY PUTRI & 2 & 2 & 2 & 1 & 7 & 58 & & $\sqrt{ }$ \\
\hline 16 & FAJAR AKBAR & 2 & 2 & 2 & 1 & 7 & 58 & & $\sqrt{ }$ \\
\hline 17 & FARAH LUTFIYAH ABDI & 2 & 2 & 3 & 3 & 10 & 83 & $\sqrt{ }$ & \\
\hline 18 & FATWATUL MIFTAHUDDIN RIZKI & 2 & 2 & 2 & 3 & 9 & 75 & $\sqrt{ }$ & \\
\hline 19 & HIDAYATULLAH PRATAMA & 2 & 2 & 3 & 2 & 9 & 75 & $\sqrt{ }$ & \\
\hline 20 & LUSI SETIAWATY BUATON & 2 & 2 & 3 & 2 & 9 & 75 & $\sqrt{ }$ & \\
\hline 21 & M. NUR FAJRIN & 3 & 2 & 2 & 3 & 10 & 83 & $\sqrt{ }$ & \\
\hline 22 & MILADHEA PUTRI GIARTO & 3 & 2 & 3 & 3 & 11 & 92 & $\sqrt{ }$ & \\
\hline 23 & MUHAMMAD DAFFA IMAMI & 3 & 2 & 3 & 2 & 10 & 83 & $\sqrt{ }$ & \\
\hline 24 & MUHAMMAD RADIVAN FIDHRIAN & 2 & 3 & 2 & 3 & 10 & 83 & $\sqrt{ }$ & \\
\hline 25 & MUTIARA KHAIRA & 2 & 2 & 2 & 3 & 9 & 75 & $\sqrt{ }$ & \\
\hline 26 & NANDA RIZKY ANDRIANTO & 2 & 3 & 3 & 3 & 11 & 92 & $\sqrt{ }$ & \\
\hline 27 & NOVAL RAMADHANI & 3 & 3 & 3 & 3 & 12 & 100 & $\sqrt{ }$ & \\
\hline 28 & PANDELA GIBRAN SATTARI & 2 & 2 & 2 & 3 & 9 & 75 & $\sqrt{ }$ & \\
\hline 29 & RAHMAT RIDO PUTRA & 2 & 2 & 2 & 3 & 9 & 75 & $\sqrt{ }$ & \\
\hline 30 & RAYVALDO G AKBAR & 2 & 2 & 2 & 3 & 9 & 75 & $\sqrt{ }$ & \\
\hline 31 & RIANTIKA SARI & 1 & 2 & 2 & 2 & 7 & 58 & & $\sqrt{ }$ \\
\hline 32 & RIKAS HIDAYAT & 2 & 2 & 2 & 3 & 9 & 75 & $\sqrt{ }$ & \\
\hline 33 & ROBIATUL ADDAWIYAH & 3 & 2 & 3 & 2 & 10 & 83 & $\sqrt{ }$ & \\
\hline
\end{tabular}


Selma Br Hutabarat, Implementasi Layanan Konseling dengan Methode Reinforcement Guna Meningkatkan Motivasi Belajar Pada Siswa Kelas XI IPA 3 SMAN 5 Kota Jambi Tahun Pelajaran 2014/2015

$\begin{array}{ll}34 & \text { SARAH IMANUELLA SIMBOLON } \\ 35 & \text { SIGIT PRIAMBUDI } \\ 36 & \text { TETTY MARIANA SIRAIT } \\ 37 & \text { TIARA HATI GIWANGKARA } \\ 38 & \text { VALENTINO ROSSI } \\ 39 & \text { VIDYA AQILA KURNIAWAN } \\ 40 & \text { WILDA APRIANTI }\end{array}$

Jumlah

$\begin{array}{llllllll}3 & 3 & 3 & 2 & 11 & 92 & \sqrt{ } & \\ 2 & 3 & 3 & 3 & 11 & 92 & \sqrt{ } & \\ 2 & 2 & 3 & 2 & 9 & 75 & \sqrt{ } & \\ 3 & 2 & 3 & 2 & 10 & 83 & \sqrt{ } & \\ 2 & 2 & 3 & 3 & 10 & 83 & \sqrt{ } & \\ 3 & 3 & 3 & 3 & 12 & 100 & \sqrt{ } & \\ 3 & 3 & 2 & 3 & 11 & 92 & \sqrt{ } & \\ & & & & & 3190 & 37 & 3\end{array}$

Jumlah seharusnya $=4000$

Jumlah yang diperoleh $=3190$

Rata-rata $=79$

Prosentase $=94 \%$

Keterangan:

a. Tekun menghadapi tugas serta ulet menghadapi kesulitan.

b. Menunjukkan minat terhadap macam-macam masalah dan mencoba belajar mandiri.

c. Sering mencari dan memecahkan soal-soal.

d. Tidak mudah melepaskan hal-hal yang sudah diyakini serta dapat mempertahankan pendapatnya.

Dari tabel di atas jelas terlihat bahwa siswa yang nilai skor diatas minimal (75\%) adalah sebesar $994 \%$.

Refleksi

Dalam pelaksanaan kegiatan belajar mengajar diperoleh informasi dari hasil pengamatan sebagai berikut:

1. Guru sudah baik dalam memotivasi siswa dan dalam menyampaikan layanan konseling.

2. Guru sudah bisa dengan baik dalam pengelolaan waktu

3. Siswa mulai antusias selama layanan konseling.

Revisi

Pelaksanaan kegiatan bimbingan konseling pada siklus II ini sudah berjalan dengan baik dan mendapatkan perubahan yang signifikan dalam kedisiplinan guru di dalam kelas berupa pelaksanaan layanan konseling.

\section{Pembahasan}

Ketercapaian Hasil belajar siswa

Melalui hasil penelitian ini menunjukkan bahwa pemberian layanan dengan methode reinforcement memiliki dampak positif dalam meningkatkan motivasi belajar siswa. Hal ini dapat dilihat dari semakin mantapnya pemahaman siswa terhadap materi yang disampaikan guru (Ketercapaian belajar meningkat dari siklus I ke II) untuk ranah psikomotor yaitu siklus I (72\%), siklus II (92\%) pada siklus II Ketercapaian nilai siswa secara klasikal.

\section{Kemampuan Guru dalam Mengelola Pembelajaran}

Berdasarkan analisis data, diperoleh aktivitas siswa dalam proses belajar mengajar dengan menerapkan metode reinforcement dalam setiap siklus mengalami peningkatan. Hal ini berdampak positif terhadap prestasi belajar siswa yaitu dapat ditunjukkan dengan meningkatnya nilai rata-rata siswa pada setiap siklus yang terus mengalami peningkatan.

\section{Aktivitas Siswa dalam Pembelajaran}

Berdasarkan analisis data, diperoleh aktivitas siswa dalam proses pembelajaran dengan model pembelajaran paling dominan adalah belajar dengan sesama anggota kelompok, mendengarkan/memperhatikan penjelasan guru dan diskusi antara siswa/antara siswa dengan guru. Jadi dapat dikatakan bahwa aktivitas siswa dapat dikategorikan aktif.

Sedangkan untuk aktivitas guru selama pembelajaran telah melaksanakan langkah-langkah metode reinforcement dengan baik. Hal ini terlihat dari aktivitas guru yang muncul di antaranya aktivitas membimbing dan mengamati siswa dalam mempraktikkan hasil pembelajaran, menjelaskan/melatih menggunakan alat, memberi umpan balik dalam prosentase untuk aktivitas di atas cukup besar.

\section{SIMPULAN}

Dari hasil kegiatan pembelajaran yang telah dilakukan selama tiga siklus dan berdasarkan seluruh pembahaan serta analisis yang telah dilakukan dapat disimpulkan bahwa: 1) layanan Bimbingan Konseling dengan metode ini memiliki dampak positif dalam meningkatkan motivasi belajar siswa yang ditandai dengan peningkatan Ketercapaian nilai siswa dalam setiap siklus, yaitu siklus I (72\%), dan siklus II (93\%), dan 2) penerapan metode layanan bimbingan konseling ini mempunyai pengaruh positif, yaitu dapat meningkatkan motivasi belajar siswa yang ditunjukkan dengan 
rata-rata jawaban siswa yang menyatakan bahwa siswa tertarik dan berminat dengan metode pembelajaran ini sehingga mereka menjati termotivasi untuk belajar. Dari hasil penelitian yang diperoleh dari uraian sebelumnya agar proses belajar mengajar lebih efektif dan lebih memberikan hasil yang optimal bagi siswa, maka disampaikan saran yakni 1) untuk melaksanakan metode pembelajaran Bimbingan Konseling memerlukan persiapan yang cukup matang, 2) perlu adanya penelitian yang lebih lanjut, karena hasil penelitian ini hanya dilakukan di SMA N 5 Kota Jambi.tahun pelajaran 2017/2018, dan 3) untuk penelitian yang serupa hendaknya dilakukan perbaikan-perbaikan agar diperoleh hasil yang lebih baik.

\section{DAFTAR PUSTAKA}

Ahmadi, Abu. 2009. Psikologi Umum. Jakarta: Rieka Cipta

Achmad, Juntika Nurihsan. 2006. Bimbingan dan Konseling Dalam Berbagai Latar dan. Kehidupan. Bandung : PT Reika Aditama

Hasibuan. Moedjiono. 2010. Proses belajar mengajar. Bandung: PT Remaja Rosdakarya.

Latipun. 2006. Psikologi Konseling. Malang: UMM Press.

Makmun, Abin Syamsuddin. 2012. Psikologi Kependidikan Perangkat Sistem Pengajaran Modul, Bandung : Remaja Rosdakarya

MC. Niff, J. 1992, Action Rersearch Principles and Practice, New York Rantidge Chapment dan Hall Inc.

Mulyasa, E. 2011. Menjadi Guru Profesional. Bandung: Remaja Rosdakarya.

Prayitno, Erman Amti. 2008. Dasar-Dasar Bimbingan dan Konseling. Jakarta: PT. Rineka Cipta.

Sardiman, A.M. 2011. Interaksi dan Motivasi Belajar Mengajar. Jakarta: PT Rajagrafindo

Soemanto, Wasty. 2012. Psikologi Pendidikan. Jakarta: Rineka Cipta

Sugiarti, Titik. 1997. Metode Penelitian Pendidikan, Bandung: Alfabeta.

Sukardi, Dewa Ketut. 2008. Pengantar Pelaksanaan Program BK di Sekolah. Jakarta: Rineka Cipta.

Usman, Moh. Uzer. 2005. Menjadi Guru Profesional. Bandung : Remaja Rosdakarya.

Winkel, W. S. 2004. Psikologi Pendidikan dan Evaluasi Belajar. Jakarta: PT. Gramedia Pustaka Utama. 